A b s t r a c t: Self-organizing teams, especially in the context of Agile Project Management are subject of interest in business and academia. Agile approach has roots in the IT industry and expending to other fields. One of the most dominant attributes of Agile approach is self-organizing teams. In the literature, self-organizing teams have been studied sine 50 s of XX century and can be described by six dimensions: autonomy, communication, learning, team orientation, shared leadership and redundancy. Also, self-organizing agile teams can be characterized by existing informal roles like a mentor, coordinator, translator, promoter, champion, terminator. In the article, the author used a case study method for examining the above characteristics of self-organizing teams. As a result, the existing theoretical models can be useful in diagnosing the state of a self-organizing team. Further studies with more strict research methods are recommended to extend knowledge about the self-organizing team in Agile Project Management.

K e y w o r d s: self-organizing teams, agile teams, agile project management

J E L C o d e: J53, L22

\title{
INTRODUCTION
}

Agile Project Management is currently gaining a great amount of interest in business and academia. In particular, the software industry is adopting expensively Agile approaches for managing projects and developing various products. In opposite to project-driven approach to project management, Agile advocates close collaboration, focus on generating business value and responding to changes. One of the crucial aspects of Agile approach is the self-organizing team. The self-organizing teams are characterized by autonomy and empowerment, responsibility, ability to allocate and plan tasks by their own.

In this paper, the author tried to make a summary of the characteristics of self-organizing teams in Agile Project Management and used the characteristics

\footnotetext{
* Contact information: Jakub Perlak, AGH w Krakowie, aleja Adama Mickiewicza 30, 30-059 Kraków, email: j.perlak@gmail.com
} 
of examining an existing project team. Main attributes are presented, such as autonomy, cross-functionality, team orientation, shared leadership, and redundancy [Moe, Dingsøyr, Dybå 2010]. Furthermore, as supplementary characteristics emerging roles in self-organized teams are presented proposed by Hoda, Noble and Marshall [2010]. The research method chosen in the article is a case study. The author used various techniques to analyze the phenomenon of a self-organizing team during observation of one team. In the end, results are presented with accompany of discussion with limitation of the study in shed light of literature review.

\section{AGILE PROJECT MANAGEMENT}

Agile Project Management currently is one of the most popular approaches to project management [Wysocki 2013; Serrador, Pinto 2015]. The Agile approach takes inspirations from Agile software development [Hoda, Murugesan 2016]. Agile methods are less planning focused and are an alternative to the traditional, plan-driven, waterfall, the plan is emerging during the curse of the project. Iterative and incremental work is favoured over planned work in phases, like separating designs and implementation work. Moreover, close collaboration with customers is preferred instead of presenting the results at the end of the project. Agile methods in various studies show an advantage over the traditional approach and are more likely to be successful [Serrado, Pinto 2015].

Agile methods are in the software industry for over two decades [Dingsøyr, et. al. 2012]. In 2001 the Agile Manifesto was published in which vision how to cope with raising complexity and difficulty of software developments is proposed [Beck, et. al. 2001]. The Agile Manifesto argues that there is more value in individuals and interactions, working software, customer collaboration and responding to changes, rather than tools, procedures, negotiations, documentation and keeping the initial plan of work. In addition to values, twelve principles are proposed in the manifesto. In one of the principles, self-organizing teams are highlighted as sources of the best architecture, requirements, and design [Beck, et. al. 2001]

\section{SELF-ORGANIZING TEAMS}

The subject of teams and self-organization has been studied in many disciplines. First studies on self-organizing teams in the management literature are related to autonomous coal miners' groups in England in years the 50s of XX century. Those groups were described as a self-managed learning system, which shared the responsibilities of supervisors [Hoda, Murugesan 2016]. Also, in the work of Burns and Stalker [1961] organic organizational structure, based on no 
strict relation among employees helps in adapting to changing the environment. Self-organizing teams are mentioned in work of Morgan and in his prominent book "Images of Organization" [1986]. Morgan described a similar type of organizing work by acceptance of redundancy, clear external task specification, independence in decision making and planning tasks [Morgan 1986]. One of the most cited publications Takeuchi and Nonaka [1986] analyzed requirements of self-organizing teams and according to them: autonomy, cross-functionality and continuous improvement are necessary fundamentals of such type of teams. Moreover, according to the authors, self-organizing teams achieve better performance in comparison to traditional teams managed by the manager.

Teams in an organization can be defined in various ways. One of the definitions proposed in the literature is an autonomous group [Guzzo, Dickson 1996]. Autonomous group working on the independent job, having authority and responsibility on every aspect of work, planning, assigning tasks, executing and all resources to perform the task. The recurring theme of self-organizing teams is autonomy, which precedes self-organization [Langfred 2000; Moe, Dingsøyr, Dybå 2010]. Self-organizing teams are empowered in decision making but also requires the organizational environment to be successful, especially culture in the organization plays an important factor in thriving teams [Sheffield, Lemétayer 2013]. Team orientation and learning are important aspects of self-organizing teams [Moe, Dingsøyr, Dybå 2010]. The support from management enables authority in everyday decision making [Hoda, Murugesan 2016]. Managers and leaders in organizations are more facilitators of self-organizing teams, ensure that team members have a supporting environment, share information and help the teams if necessary [Druskat, Wheeler 2003].

Looking at characteristics of self-organizing teams it is worth to mention the informal roles in the team. Hoda and Marshall [2010] distinguish six roles in self-organizing teams, each role can be taken by more than by one team member. A mentor is a team member focused on coaching and mentoring others, whereas a coordinator helps in the whole process. On the other hand, a translator is a person who is an intermediate of business and team members. A promotor share idea and looking for innovations, however, a champion is looking helping with support of the organization. Finally, a terminator who is looking for a hole in the system. Each of the roles is important in shaping the self-organizing teams, especially the role of the champion and the promotor are crucial at the begging of self-organization [Hoda, Noble, Marshall 2010].

In the summary of the characteristics of self-organizing teams, the author combines the six dimensions of self-organization with informal roles. 
Figure 16 dimensions with roles

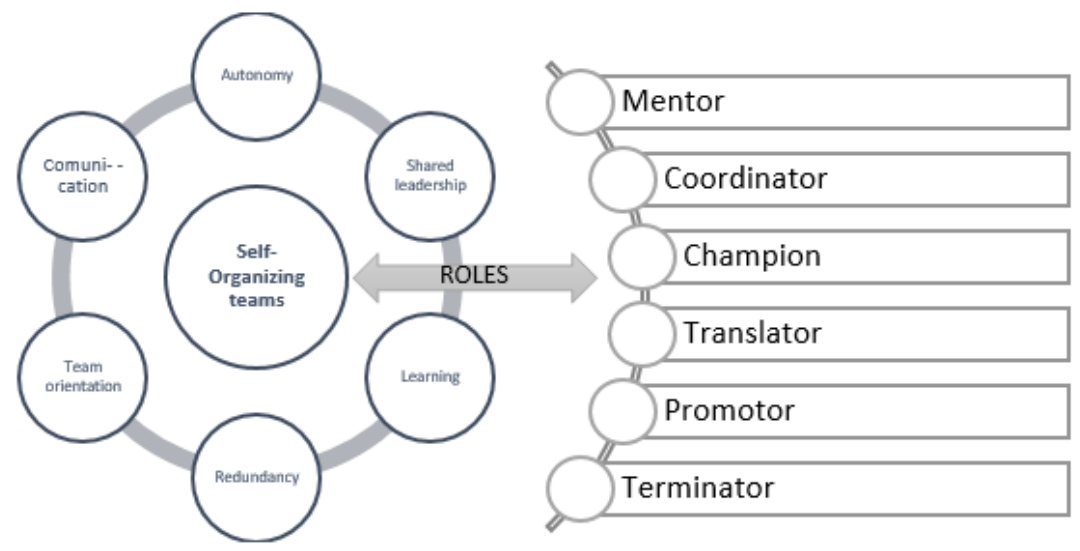

Source: [Moe, Dingsøyr, Dybå 2010; Hoda, Noble, Marshall 2010;. [Helsinki, Karhatsu 2010]

The five dimensions (autonomy, shared leadership, learning, redundancy, team orientation) argued in the work of Moe, Dingsøyr, and Dybå [2010] was used in the research for dragonizing teams. Additional dimension, a communication was proposed by Helsinki and Karhatsu [2010] as an important not forgotten factors which enable self-organization. All of the dimensions are rooted in the literature of self-organizing teams. The roles are characterized by Hoda, Noble and Marshall [2010]. The six dimensions and the roles were a theoretical foundation for the own research conducted by the author.

\section{RESEARCH METHOD}

The research method used in this research was a case study. The case study is well established in the science of management. The method is used for various aims: as a base for generating new theory, validating and testing existing theory to some extent and in the purpose of education [Czakon 2015]. The research described in the article tried to validate the dimensions of the self-organizing team and the informal roles within the team. The study tried how those two concepts help to better understand the self-organization in Agile Project Management. The was conducted according to the procedure in the figure.

Tools used in the case study were participatory observation, a questionnaire and semi--structure interview with the team members. The questionnaire was constructed with 6 questions about the roles of how strongly someone identified the role of Liker scale 1-5. Similarly, the dimensions were represented by four questions per each dimension, the same Likert scale was used. 
Figure 2 The procedure of the case study

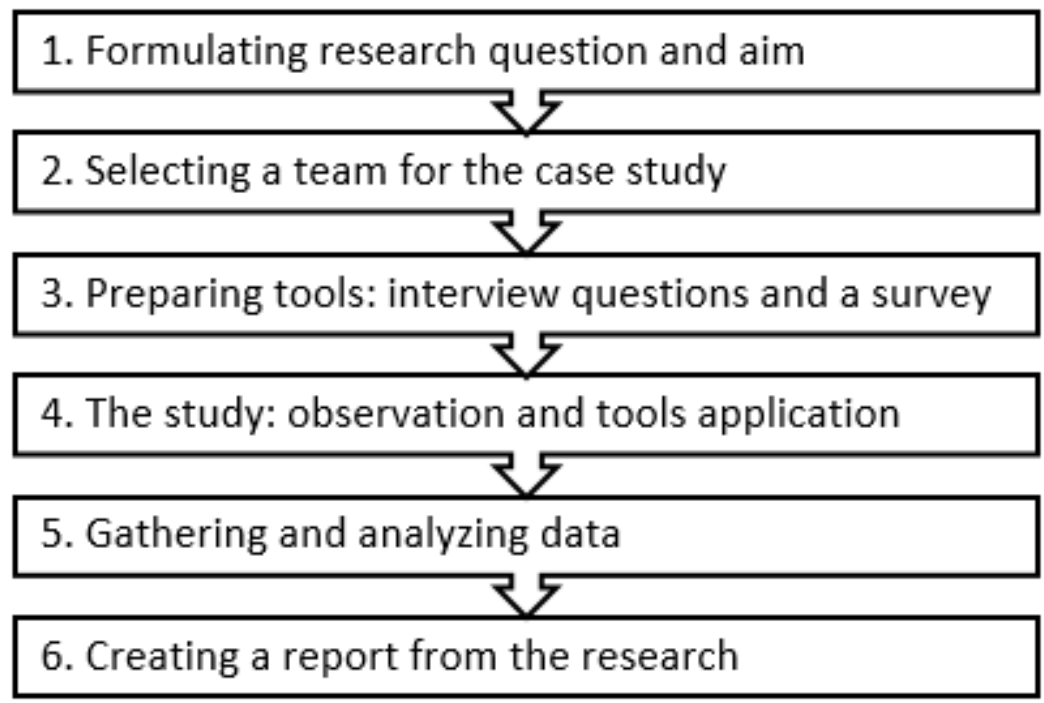

\section{Source: own}

Tools used in the case study were participatory observation, a questionnaire and semi--structure interview with the team members. The questionnaire was constructed with 6 questions about the roles of how strongly someone identified the role of Liker scale 1-5. Similarly, the dimensions were represented by four questions per each dimension, the same Likert scale was used.

The research was conducted in 2019, starting from January to April. In a large IT company based in Krakow (over 500 people employed), specializing in software products for various industries and in outsourcing. The author is a Project Manager and one of his team was examined in the light of self-organizing team characteristics. The team was working with the client on an online platform. The project was managed with Agile approach. All the team members were informed that a process of collecting data during the semi-structured interviews, as well as the questionnaire, is anonymous and for and only academic purposes. Furthermore, the participants have the right to no take in the study.

The team was composed of 8 people, one team leader, one project manager and 6 developers. The responsibilities of the were related to project work: adding new functionalities, fixing defects in the system and improving work in the project. The work was observed by the author as well as in the course of observations the team members were asked to fill the questionnaire and perform semi-structure interviews about the work. 


\section{RESULTS}

Data collected from the questionnaire and semi-structured interviews is presented in this section. The questionnaire was filled by six team members and interviews were conducted with all team members. The dimensions of the self-organizing teams were examined during the questionnaire created by the author. As a result of grouping average answers from the questionnaire, a summary radar graph was created. The weakest dimensions in the examined team were learning and autonomy, on the other hand, the highest was communication and team orientation. These findings correspond with observation and interviews. The team has struggled with autonomy and learning. The team members cannot find time for learning and organizing dedicated time for improving their skills. Also, some of the team members identified that they cannot learn from others. The team identified an issue depending on the client's process. The result in the autonomy dimension was low. As autonomy is fundamental for self-organization [Langfred 2000, Hoda, Murugesan 2016], some issues (the team is waiting for external guidance) of the team can be understood and hinder the self-organizing process. In general, the team members felt satisfied with communication in the team. However, an aspect of shared leadership is far from perfect, according to an interview with the team leader, despite relatively high result (3.8/5). The dimension of team orientation seems to be relatively high, according to interviews and observation the team members have strong professional relationships.

Figure 3 The six dimensions of the self-organizing team

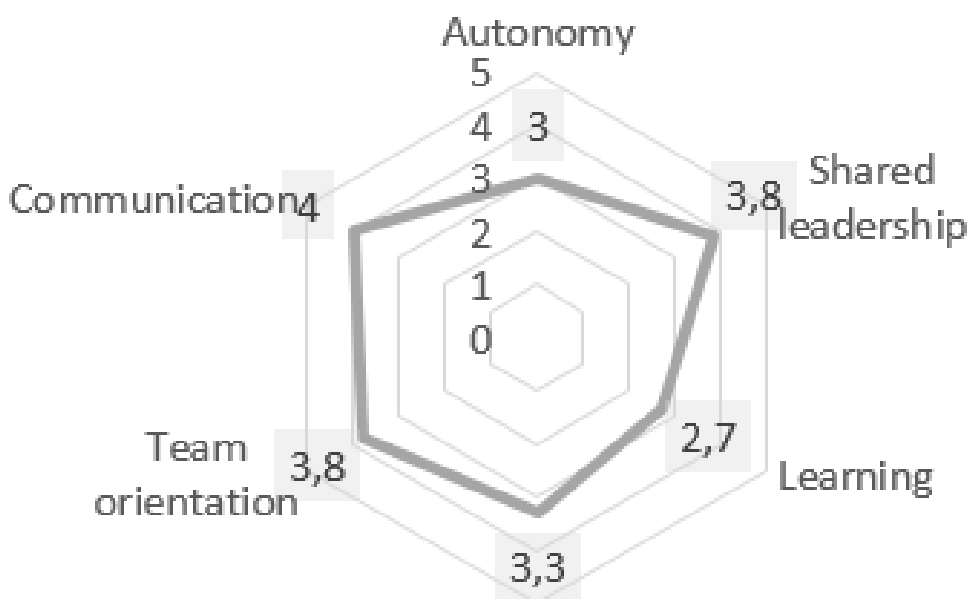

Redundancy 
As a complementary data, in the table, the answers with the highest and lowest points are presented.

Table 1 Answers in the questionnaire about dimensions of self-organizing teams

\begin{tabular}{|c|c|c|}
\hline & $\begin{array}{l}\text { Average } \\
\text { points (1-5) }\end{array}$ & Dimension \\
\hline \multicolumn{3}{|c|}{ Highest answers } \\
\hline My team works independently from other teams. & 4,4 & Autonomy \\
\hline I am willing to help others if I am asked. & 4,8 & Team orientation \\
\hline $\begin{array}{l}\text { I can share information about my work during regular meet- } \\
\text { ings. }\end{array}$ & 4,4 & Shared leadership \\
\hline \multicolumn{3}{|l|}{ Lowest answers } \\
\hline Nobody outside of the team can force a solution. & 1,6 & Autonomy \\
\hline I can learn from other team members. & 2,4 & Learning \\
\hline $\begin{array}{l}\text { I can speak about my development with other team mem- } \\
\text { bers. }\end{array}$ & 2,2 & Learning \\
\hline
\end{tabular}

Source: own

During the study, the author looked at the informal roles: mentor, coordinator, translator, champion, promoter and terminator. From the questionnaire results are as follows.

Table 2 Answers in the questionnaire about roles in self-organizing teams

\begin{tabular}{|l|c|c|c|}
\hline \multicolumn{1}{|c|}{ Roles } & Max answer & Average answer & $\begin{array}{c}\text { No. of answers: ,agree” } \\
\text { and ,strongly agree” }\end{array}$ \\
\hline Mentor & 5 & 4 & 3 \\
\hline Coordinator & 5 & 2,8 & 1 \\
\hline Translator & 5 & 3,4 & 2 \\
\hline Champion & 5 & 2,2 & 1 \\
\hline Promoter & 5 & 2,8 & 3 \\
\hline Terminator & 4 & 3,4 & 1 \\
\hline
\end{tabular}

Source: own

The most frequent role in the team was the mentor. Furthermore, a relatively high number of people felt that the terminator is the role describing them. According to research [Hoda, Noble, Marshall 2010], the role of the terminator is 
helpful but too many people can be problematic. In fact, from observation the team during the team's meetings that too much negative views were presented. On the other hand, the low number of coordinators, champions and promoters had a negative effect on the potential of the self-organizing team [Hoda, Murugesan 2016]. Confronting this with interview findings, the team leader was overloaded with the role of coordination, champion and promoter.

From the research, the team is still on the way to be a full self-organized team. The dimensions and informal roles were helpful in identify and confirm observed issues.

\section{DISCUSSION}

The purpose of the article was trying to present the characteristics of self-organizing teams in Agile projects. The self-organizing teams can be analyzed in dimensions [Moe, Dingsøyr, Dybå 2010] autonomy, communication, team orientation, redundancy, shared leadership, learning and redundancy. Moreover, in self-organizing teams informal roles which foster the process can be identified. According to research [Hoda, Murugesan 2016], a team member can be a mentor, promotor, translator, coordinator, champion, terminator. Looking at the results of the research the author found practical usefulness of dimensions concept and informal roles as tools for better understanding the team. A further application, on more teams, can be beneficial.

The limitation of the case study, like fragmentary data, subjective interpretation can be problematic [Czakon 2015]. However, the author found the concept presented in the article very useful in analyzing and diagnosing the potential issue with self-organizing teams in Agile project management. Further research, adding more theoretical concepts, as well as adding other research methods seems to be a very interesting direction in understating the self-organizing teams.

\section{LITERATURE}

Beck, K., Beedle, M., van Bennekum, A., Cockburn, A., Cunningham, W., Fowler, M., ... Thomas, D. (2001). Manifesto for Agile Software Development. Retrieved February 7, 2019, from https://agilemanifesto.org/

Burns, T. and Stalker, G. (1961). The Management of Innovation. London:Tavistock.

Czakon, W. (red. . (2015). Podstawy metodologii badań w naukach o zarządzaniu. Igarss 2014, (April), 455.

Dingsøyr, T., Nerur, S., Balijepally, V., \& Moe, N. B. (2012). A decade of agile methodologies: Towards explaining agile software development. Journal of Systems and Software.

Druskat, V. U., \& Wheeler, J. V. (2003). Managing from the boundary: The effective leadership of self-managing work teams. Academy of Management Journal, 46(4), 435-457. 7

Guzzo, R. A., \& Dickson, M. W. (1996). TEAMS IN ORGANIZATIONS: Recent Research on Performance and Effectiveness. Annual Review of Psychology, 47(1), 307-338. 
Helsinki, H. K., \& Karhatsu, H. (2010). Building a Self-organizing Software Development Team: Multiple Case Study.

Hoda, R., \& Murugesan, L. K. (2016). Multi-level agile project management challenges: A self-organizing team perspective. Journal of Systems and Software, 117, 245-257.

Hoda, R., Noble, J., \& Marshall, S. (2010). Organizing Self-Organizing Teams. Association of Computer Manufacturers Journal.

Langfred, C. W. (2000). The paradox of self-management: Individual and group autonomy in work groups. Journal of Organizational Behavior, 21, 563.

Moe, N. B., Dingsøyr, T., \& Dybå, T. (2010). A teamwork model for understanding an agile team: A case study of a Scrum project. Information and Software Technology, 52(5), 480-491.

Takeuchi, H., \& Nonaka, I. (1986). New Product Development Game. Harvard Business Review, 64, 137-146.

Sheffield, J., \& Lemétayer, J. (2013). Factors associated with the software development agility of successful projects. International Journal of Project Management, 31(3), 459-472. 1

Serrador, P., \& Pinto, J. K. (2015). Does Agile work? - A quantitative analysis of agile project success. International Journal of Project Management.

Takeuchi, H., \& Nonaka, I. (1986). New Product Development Game. Harvard Business Review, 64, 137-146.

Wysocki, R. K. (2013). Effective Project Management: Traditional, Agile, Extreme (7th ed.). Wiley Publishing.

\section{CHARAKTERYSTYKA SAMOORGANIZUJĄCYCH SIĘ ZESPOŁÓW W ZWINNYM ZARZĄDZANIU PROJEKTAMI: STUDIUM PRZYPADKU}

Zarys treści: Samoorganizujące się zespoły projektowe, zwłaszcza w kontekście zwinnego zarządzania projektami, są tematem zainteresowania praktyków biznesu i badaczy naukowych. Podejście zwinne ma swoje korzenie w branży IT ale jego popularność stale rośnie, również w innych branżach. Jednym z kluczowych atrybutów podejścia zwinnego są samoorganizujące się zespoły. W literaturze, samoorganizujące się zespoły są badane od lat 50-tych XX wieku i mogą być opisane, między innymi, przy pomocy szczęściu wymiarów: autonomii, komunikacji, uczenia się, zorientowania na zespół, wspólnego przewodzenia i zastępowalności. Jak również, samoorganizujące się zwinne zespoły charakteryzują się powstawaniem nieformalny ról takich jak: mentor, koordynator, tłumacz, promotor, czempion czy terminator. W badaniu własnym użyto metodę studium przypadku, w którym to sprawdzono przydatność wymienionych koncepcji w ramach analizy pracy wybranego zespołu. W rezultacie, zarówno wymiary, jak i nieformalne role okazały się pomocnym narzędziem diagnostycznym stanu samoorganizacji zespołu. Zalecane są dalsze badania z wykorzystaniem bardziej rygorystycznych metod badawczych w celu odkrywania właściwości samoorganizujących się zespołów w zwinnym zarządzaniu projektami.

Słowa kluczowe: samoorganizujące się zespoły, zwinne zespoły, zwinne zarządzanie projektami 
